
pokolenia mieszkańców wsi. Slavia Meridionalis, 21, Article 2408. https://doi.org/10.11649/sm.2408

\title{
Beata Ziajka
}

Uniwersytet Jagielloński

https://orcid.org/0000-0002-7562-6265

\section{Nowe zachowania językowe u najstarszego pokolenia mieszkańców wsi}

Powszechnie wiadomo, że współczesna wieś w coraz większym stopniu poddaje się uniwersalizującym oddziaływaniom kultury ogólnopolskiej. Dynamicznie zmieniające się realia życia, związane m.in. z rozwojem technologicznym, a także zapoczątkowane po II wojnie światowej przemiany społeczno-ekonomiczne i cywilizacyjne, jak również nasilające się w ostatnich latach procesy globalizacyjne wymuszają zmiany zachowań językowych mieszkańców wsi, które widoczne są m.in. w uzupełnianiu gwarowych systemów leksykalnych o jednostki językowe odnoszące się do nowych zjawisk społeczno-kulturowych oraz osiągnięć nauki, techniki i cywilizacji (Kurek, 2003, ss. 27-29, 2014, ss. 45-54, 2018, ss. 203-209). „Gwara będąca kodem wystarczającym do precyzyjnego i drobiazgowego opisu realiów tradycyjnej wsi - pisze A. Piechnik - stała się językiem niewystarczającym do mówienia o zmieniającym się świecie" (Piechnik, 2019, s. 8). Mieszkańcy wsi,

This work was supported by the Polish Ministry of Education and Science.

Competing interests: no competing interests have been declared.

Publisher: Institute of Slavic Studies, Polish Academy of Sciences.

This is an Open Access article distributed under the terms of the Creative Commons Attribution 3.0 PL License (creativecommons.org/licenses/by/3.0/pl/), which permits redistribution, commercial and non-commercial, provided that the article is properly cited. (c) The Author(s) 2021. 
chcąc dostosować się werbalnie do zmieniającej się rzeczywistości, próbują włączać do repertuaru językowego formy przejęte z polszczyzny ogólnej, częstokroć niemieszczące się w sferze kulturowej, społecznej i obyczajowej wiejskich wspólnot (Pelcowa, 2002b, ss. 23-36, ss. 373-397; Ziajka, 2014). $\mathrm{Z}$ jednej strony prowadzi to do ujednolicenia systemu językowego, poszukiwania wspólnej płaszczyzny porozumienia różnych pokoleń mieszkańców wsi, z drugiej zaś powoduje rozchwianie systemowe, które niejednokrotnie prowadzi do zakłóceń w toku komunikacji. Nie bez znaczenia są tutaj socjolingwistyczne determinanty określonych zjawisk językowych, wśród których dużą rolę odgrywa wiek użytkowników języka (Cygan, 2002; Kurek, 1995, 2012). Oczywiste jest, że badania starszej warstwy słownictwa, a w przypadku mieszkańców wsi także leksyki dyferencyjnej, są prowadzone wśród najstarszej generacji, neologizmy zaś bada się głównie w pokoleniu młodym (Piechnik, 2015, s. 460, 2016, ss. 300-307). Jeżeli idzie natomiast o analizę zmiennej kulturowej, będącej konsekwencją wieloaspektowych procesów unifikacyjnych zachodzących $\mathrm{w}$ środowisku wiejskim, najlepsze rezultaty przynosi uwzględnienie płaszczyzny leksykalnej pokolenia najstarszego. Jak twierdzi bowiem B. Dunaj, „to właśnie sfera leksykalno-semantyczna, a także komunikacyjna decyduje o odczuwaniu zmian jako szybkich, dynamicznych bądź wolnych" (Dunaj, 2000, s. 27). Pojawiające się w języku starszych generacji pokłady słownictwa nazywającego pojęcia i zjawiska nowe, a zatem nieznane dotąd przeciętnemu użytkownikowi gwary, obrazują sposób orientacji „prostego człowieka" w niejednokrotnie obcej rzeczywistości. Jak pisze S. Cygan, „podłożem zmian w leksyce są m.in. przemiany społeczno-kulturowe na wsi, których świadkami, a zarazem uczestnikami są przede wszystkim najstarsi mieszkańcy wsi" (Cygan, 2002, s. 85). Punkt widzenia najstarszej generacji jest zatem szczególnie interesujący, ponieważ w wypowiedziach tej grupy wiekowej doświadczenie przeszłości łączy się z wnikliwą obserwacją i wartościowaniem współczesności (Piechnik-Dębiec, 2011, s. 147). Obok podsystemu leksykalnego, wykazującego najmocniejszy związek z rzeczywistością pozajęzykową (Kąś \& Kurek, 2001, s. 450), istotny jest także aspekt pragmatyczny, czyli działanie językowe mieszkańców wsi w odniesieniu do konkretnej sytuacji komunikacyjnej ${ }^{1}$. Kształt wypowiedzi zależy bowiem od tego, kto mówi, do kogo, w jakiej sytuacji i w jakim celu (Grabias, 1991, ss. 50-52).

${ }^{1}$ Na rolę czynnika sytuacyjnego w akcie komunikacji zwracali uwagę m.in. B. Dunaj (Dunaj, 1985) i S. Grabias (Grabias, 1991, 1994). 
Wypowiedzi najstarszych mieszkańców wsi stanowią tym samym wdzięczny obiekt badawczy, ponieważ ukazują zarówno językowo-kulturowe mechanizmy włączania słowa w strukturę społeczno-obyczajową wsi, jak również odsłaniają elementy dyskursywne wynikające $\mathrm{z}$ dialogowości procesu komunikacji. Uwzględnienie w badaniach języka wsi płaszczyzn komunikacyjnej i kulturowej wyrasta z przekonania, że opisując problem interferencji leksykalnej powinno się pokazywać język w działaniach komunikacyjnych (Kurek, 2003, s. 173). Jednak jak podkreśla J. Kąś - „interferencji [leksykalnej - BZ] w gwarach niepodobna rozpatrywać w oderwaniu od interferencji kulturowej" (Kąś, 1992, ss. 95-96).

Przedmiotem zainteresowania w niniejszym tekście będzie zatem zespół czynników językowych, psychologicznych, socjalnych, które wpływają na wprowadzenie do wypowiedzi nowych form językowych rozumianych jako atrakcyjny dla mieszkańców wsi wzorzec językowo-kulturowy.

Materiał egzemplifikacyjny artykułu stanowią zachowania językowe najstarszego pokolenia (powyżej siedemdziesiątego roku życia) mieszkańców dwóch małopolskich wsi - Zagórza i Mętkowa należących do gminy Babice w powiecie chrzanowskim. Analizowane zdarzenia komunikacyjne zaistniały w latach 2015-2020 w sytuacjach nieoficjalnych, na poziomie mikrosytuacyjnego użycia języka (Kurek, 2003, ss. 127-128).

Jak już powiedziano, współczesne uwarunkowania społeczne i kulturowe zmuszają najstarsze pokolenie mieszkańców wsi do podejmowania działań językowych nie zawsze typowych dla kontaktów wewnątrzgwarowych. W licznych artykułach H. Pelcowa zwracała uwagę, że w ostatnich latach zasób leksykalny społeczności wiejskiej poszerzył się o dużą grupę wyrazów zupełnie dotąd obcych przeciętnemu użytkownikowi gwary. Są to głównie nazwy nowo wprowadzonych w obieg ogólnych pojęć, m.in. uwydatniających postęp techniczny czy też przybliżających zagadnienia z zakresu polityki i gospodarki (Pelcowa, 2002b, s. 23). „Konieczność cywilizacyjna” (Pelcowa, 2002b, s. 30) sprawiła, że większość tych nazw przyjęła się na wsi i tworzy wspólną dla wszystkich grup wiekowych warstwę języka. Tworzeniu międzygeneracyjnej wspólnoty komunikatywnej sprzyjają również zapożyczenia międzypokoleniowe (Pelcowa, 2002b, s. 26), które w języku najstarszych mieszkańców wsi pojawiają się jednak nie tylko $\mathrm{w}$ kontaktach $\mathrm{z}$ pokoleniem młodszym. W poniższym zdarzeniu komunikacyjnym uczestniczą osoby z najstarszej grupy wiekowej, reprezentujące tożsamy typ kulturowy:

A: a tyn nojstarszy wnuk to cie łodwiedzo?

B: a skund. 
A: to muoze na świynta przyjedzie?

B: teroz żeby do babki przyjechać to trza kasik zabukować w systemie, a jo nie wiym, jak to się dugo bukuje. Nie do pomyślynio, jak to sie teroz żyje.

Zaistniały w replice uczestniczki aktu mowy leksem bukować, reprezentujący najnowszą warstwę języka, stanowi typowy przykład zapożyczenia międzypokoleniowego, funkcjonuje bowiem w wypowiedzi interlokutorki na zasadzie cytatu z języka wnuka. O tym, że jest to jednostka pochodząca z systemu sekundarnego, świadczy powielanie przez mieszkankę wsi poznanego w wyniku komunikacji z wnukiem kontekstu w zakresie łączliwości wyrazu bukować z inną - również pochodzącą spoza macierzystego kodu - jednostką leksykalną (zabukować w systemie). Powyższe zachowanie językowe obrazuje zatem działanie filtru sytuacyjnego realizującego się poprzez filtr aktywnego poznania, który rozumiem za J. Kąsiem jako złożony zespół czynników językowych, psychologicznych i socjalnych wpływających na wprowadzenie do wypowiedzi jednostek nowych, przejmowanych z systemu sekundarnego na zasadzie przywołania konsytuacji, w których używano ich aktywnie w przeszłości (Kąś, 1994, ss. 64-73).

Jak pisze H. Kurek, „w procesie komunikacji wyboru nazwy [...] dokonuje się w zależności od potrzeb aktu komunikacyjnego, a zwłaszcza jego skuteczności" (Kurek, 2003, s. 120). W przypadku analizowanego aktu mownego użycie leksemu obcego jest wynikiem przyjęcia przez interlokutorkę pewnej strategii mówienia mającej na celu zdyskwalifikowanie w oczach odbiorcy zachowań zaburzających usankcjonowany na wsi ład społeczny. Dystans mieszkanki wsi wobec nowej formy aktywności, niezakorzenionej w realiach wiejskich, wyraża się także poprzez występujący przed czasownikiem zaimek nieokreślony kasik 'gdzieś' (trza kasik zabukować), którego użycie uzewnętrznia brak dostatecznej wiedzy na temat treści znaczeniowych wnoszonych przez verbum. Pojawienie się dodatkowego wyrazu w postaci wykładnika nieokreśloności kasik wskazuje ponadto, że stojące po czasowniku wyrażenie przyimkowe do systemu nie ma dla mówiącego wartości semantycznej doprecyzowującej znaczenie czasownika. Niewiedzę semantyczną potęguje fakt, że leksem bukować jest nazwą czynności, zaś wyraz system należy do pojęć abstrakcyjnych, które w o wiele mniejszym stopniu są przyswajane przez członków wiejskiej wspólnoty. Jak zauważył bowiem M. Kucała, w procesie interferencji leksykalnej „najłatwiej przejmuje się nazwy rzeczy konkretnych [...] trudniej przyswajają się [natomiast - BZ] pojęcia oderwane, czynności i stany niemające wyraźnie zarysowanych konturów" (Kucała, 1960, s. 155). 
Wskaźnikiem dystansu wobec nowej rzeczywistości jest także wyraźnie zarysowująca się w wypowiedzi mieszkanki opozycja chronologiczna dawniej : teraz ${ }^{2}$, która nabiera cech opozycji aksjologicznej sprowadzającej się do negatywnego wartościowania teraźniejszości widzianej przez pryzmat zmian dokonujących się w sferze zachowań wewnątrzrodzinnych.

W zebranym materiale językowym nader często pojawiają się także różnego rodzaju innowacje leksykalne ${ }^{3}$. Sposób rozumienia i właściwego kontekstualnego użycia określonego leksemu ogólnopolskiego wiąże się bowiem ściśle z kompetencją językową (Kucała, 1960; Pelcowa, 2000), której w odniesieniu do polszczyzny ogólnej brakuje szczególnie najstarszemu pokoleniu mieszkańców wsi ${ }^{4}$. R. Kucharzyk, badająca język wsi z perspektywy autochtonów, zwróciła uwagę, że „użytkownicy gwary wskazują, że jest wiele takich leksemów, które funkcjonują w języku ogólnym, a dla nich są niezrozumiałe" (Kucharzyk, 2002, s. 284). W procesie przyjmowania do gwar nazw nowych desygnatów dochodzi zatem do licznych przekształceń fonetyczno-morfologicznych (por. Burska-Ratajczyk, 2004). Niejednokrotnie nowe jednostki leksykalne dostosowują się do systemu danej gwary w płaszczyźnie fonetycznej:

Jo tyż miałak problem z zasięgiem. Syn mi teroz wzion [telefon] z oryndża, to zoboczymy.

Większość innowacji leksykalnych to jednak twory paronimiczne (Grabias, 1982), powstałe na skutek skojarzenia opartego na brzmieniowym podobieństwie wyrazów:

A: dziołcho, jak sie ino troche zwieczerzy, to łuny siadają na rowery i jeżdżą po wsi, na zwiady. Jak sie u kogo światło świyci, to paczum, jak mo w domu. Dziołcho, trza aluzje [żaluzje] zasuwać! Dewoty pierojskie!

B1: wiysz już, kiedy bedzie u nos ksiądz?

B2: jeszcze nie głosił, ale Błożynka godała, że trza tam wpisać w tego bubla [google’a] w komputerze i sie podobno cało kolynda pokazuje.

${ }^{2}$ Na temat opozycji dawny : współczesny oraz gwarowych kwalifikatorów leksykalnych będących przejawem świadomości językowej mieszkańców wsi pisali m.in. H. Pelcowa (Pelcowa, 1999, ss. 263-264, 2009, ss. 91-92) oraz S. Cygan (Cygan, 2002).

3 Za innowację leksykalną uznaję za B. Burską-Ratajczyk „wyraz, zwrot, znaczenie wyrazu, będące w użyciu w mowie mieszkańców wsi, a nie występujące w polszczyźnie ogólnej; wyraz, który w różny sposób odbiega od normatywnych jednostek leksykalnych, zarejestrowanych w słownikach" (Burska-Ratajczyk, 2004, s. 248).

${ }^{4}$ Najstarsi mieszkańcy wsi mają natomiast kompetencję językową w zakresie znajomości własnej gwary i posługiwania się nią (por. Kurek, 1994, s. 111; Pelcowa, 2000). 
C1: zaś miała atak ty aplikacji.

C2: chyba epilepsji.

C1: no, ty padaczki.

W monograficznym opracowaniu etymologii ludowej W. Cienkowski (Cienkowski, 1972) wprowadził podział na wyrazy etymologicznie słabe i mocne. Za wyrazy słabe uznał leksemy nieprzejrzyste semantycznie, za mocne natomiast jednostki transparentne, powiązane etymologicznymi relacjami z resztą słownika. $\mathrm{W}$ wyniku kojarzenia wyrazu słabego $\mathrm{z}$ mocnym następuje reinterpretacja etymologiczna wyrazu słabego. W przypadku powyższych zdarzeń komunikacyjnych relacją wyrazu mocnego do słabego należałoby prawdopodobnie tłumaczyć pojawienie się w akcie mownym powszechnego w użyciu wyrazu bubel w znaczeniu 'google'. Powstanie innowacji leksykalnej ma zapewne związek z tym, że słownictwo z zakresu technologii informatycznych wciąż reprezentuje warstwę języka słabo przyswojoną przez osoby starsze. Skategoryzowanie przestrzeni komputerowej jako obcej pozostaje w związku z pojawiającym się w wypowiedzi mieszkanki Mętkowa wykładnikiem modalności epistemicznej podobno, który wyraża niepewność mówiącej nie tyle co do prawdomówności osoby, od której pozyskano informację, co wobec samego internetowego źródła przekazu. Niepewność wyrażona przywołaną jednostką modalną może także być spowodowana nieznajomością bądź ograniczoną znajomością przestrzeni internetowej przez rozmówczynię.

W przypadku pozostałych sytuacji komunikacyjnych trudno mówić o etymologii ludowej, ponieważ w koncepcji W. Cienkowskiego kierunek jej zachodzenia przebiega od wyrazów nieprzejrzystych semantycznie do wyrazów mocnych. Proces paronimii ${ }^{5} \mathrm{w}$ omawianych przykładach $(\mathrm{A}, \mathrm{C})$ wynika natomiast $\mathrm{z}$ wzajemnego oddziaływania na siebie dwóch wyrazów obcych polszczyźnie ludowej, a zatem słabych etymologicznie, co w rezultacie prowadzi do powstania błędów językowych: aluzje 'żaluzje', aplikacja 'epilepsja'. Jedynie w przypadku użytego w wypowiedzi mieszkanki Zagórza leksemu 'aplikacja' można by uznać jego przewagę nad terminem medycznym 'epilepsja' ze względu na wysoką frekwencję wyrazu aplikacja w przestrzeni medialnej. Jednostka językowa jest zatem znana mieszkańcom wsi, co nie zmienia faktu, że w tym kontekście została użyta w niewłaściwym znaczeniu. Przyswajanie leksyki obcej przez starszych mieszkańców wsi często bowiem ma charakter automatyczny i sprowadza się do zaadaptowania strony brzmieniowej wyrazu bez pełnej znajomości jego semantyki (Burska-Ratajczyk, 2002, s. 72).

\footnotetext{
5 Na temat paronimii jako procesu leksykalnego pisał S. Grabias (Grabias, 1982).
} 
Czasem stopień rozpoznania semantycznego nowej jednostki jest duży, a o jej obcości w systemie gwarowym świadczy jedynie deformacja postaci wyrazu:

Możesz ji haw pod łogon chłopów wrazić $c^{6}$, jak łona pedziała, że kce być tą singlą.

Powszechnie wiadomo, że jednym z powodów adaptacji nowych elementów językowo-kulturowych jest niemożność znalezienia ich ekwiwalentów znaczeniowych wśród jednostek kodu prymarnego. W przypadku powyższej wypowiedzi istnieją jednak rodzime odpowiedniki wyrazu singielka w postaci leksemu panna bądź synonimicznych konstrukcji analitycznych typu 'osoba niepozostająca w związku’. Wyczuwane przez młode pokolenie użytkowników języka różnice semantyczne pomiędzy warstwą rodzimą a zapożyczeniem, odsłaniające niezwerbalizowany w definicji 'panny', a obecny w strukturze znaczeniowej anglicyzmu komponent 'niezamężna i niepozostająca w związku', często $\mathrm{z}$ własnego wyboru', nie wydają się na tyle czytelne dla starszego pokolenia, by celowo używało jednostki zapożyczonej ze względu na wnoszony przez nią dodatkowy sem. Bardziej prawdopodobne wydaje się, że leksem, choć zmodyfikowany formalnie, zaistniał w akcie komunikacji w charakterze zniekształconego cytatu z wypowiedzi osoby, której dotyczy rozmowa. Warto jednak zwrócić uwagę, że przywołana przez mieszkankę Mętkowa jednostka nazewnicza ma charakter silnie wartościujący, podobnie jak nacechowanie emocjonalne całej wypowiedzi. Negatywny wydźwięk aktu mownego jednoznacznie wskazuje, że tradycyjna społeczność wiejska w dalszym ciągu z dużą dozą krytycyzmu odnosi się do osób samotnych z wyboru (por. Piechnik, 2009, ss. 121-122; Ziajka, 2014, ss. 263-265).

W niektórych przytoczonych wyżej wypowiedziach nowe jednostki językowe bywają używane w kolokacji z zaimkiem deiktycznym ten (tą singla, tego bubla, ty aplikacji). Zaimek ten, stojąc przy rzeczowniku, jak pisze W. Miodunka, „indywidualizuje i konkretyzuje go, mogąc być równocześnie sygnałem stopnia znajomości jego treści. Pod tym względem ten ma zdolność denotowania przedmiotu, którego treść (razem z cechami typowo indywidualnymi) jest znana zarówno mówiącemu, jak i słuchaczowi” (Miodunka, 1974, s. 49). W przypadku analizowanych aktów komunikacyjnych rzeczownik pozostający w polu wskazywania zaimka w świadomości mówiących jest językowym reprezentantem

${ }^{6} \mathrm{Na}$ badanym obszarze fraza ta funkcjonuje w znaczeniu 'mieć do czegoś obojętny bądź negatywny stosunek'.

7 Wielki słownik języka polskiego IJP PAN definiuje singielkę jako 'kobietę niemającą partnera życiowego'. 
rzeczywistości obcej realiom wiejskim. Użycie zaimka może zatem służyć nie tylko wyróżnieniu obiektu, ale także intensyfikacji dystansu mówiącego wobec własnej, aczkolwiek zapożyczonej leksyki, co zawiera się w eksplikacji 'to, o czym mówię, jest mi znane, ale obce kulturowo'. Funkcja występującego przy rzeczowniku zaimka jest więc zbliżona do funkcji pełnionej przez tzw. operatory metatekstowe czy operatory dystansowania (Cygan, 2002, s. 85; Kąś, 1994, s. 41), które wprowadzane są do wypowiedzi gwarowych w celu odróżnienia różnych złóż dialektalnej leksyki. Wspomniane operatory w większości jednak sygnalizują dystans wobec słownictwa gwarowego, mają bowiem, jak pisze J. Kąś, przekonać niegwarowego słuchacza o tym, że nadawca komunikatu jest świadomy dialektalnego charakteru użytych jednostek językowych (Kąś, 1994, s. 41). W odróżnieniu od operatorów metatekstowych, które stanowią jawne wykładniki wartościowania kulturowego, dystans podmiotu mówiącego nie wynika z zastosowania samych form zaimków, lecz z ich użycia w kolokacji $\mathrm{z}$ nieprzyswojoną kulturowo jednostką językową. W tym względzie funkcja zaimków polega na akcentowaniu przynależności użytego po nim wyrazu do warstwy leksyki obcej kulturowo społeczności wiejskiej.

W konstruowaniu strategii komunikacyjnych mieszkańcy wsi chętnie wykorzystują leksykę nową, modną, popularyzowaną przez środki masowego przekazu, a także pojawiającą się w języku młodego pokolenia. Niejednokrotnie przedstawiciele najstarszej generacji sięgając po tę leksykę, nie mają jednak świadomości, że umiejscowienie słowa w rzeczywistości pozajęzykowej przekracza ich kompetencję w zakresie znajomości słownictwa ogólnego, w związku z czym pojawiające się w mowie starszych osób jednostki językowe są wyabstrahowane $\mathrm{z}$ ich socjalno-kulturowego podłoża. Potrzeba użycia wyrazu modnego, funkcjonującego w przestrzeni medialnej, jest jednak na tyle silna, że decyduje o jego pojawieniu się nawet w kontakcie z przedstawicielami tożsamej wspólnoty kulturowej, z którymi rozmówca komunikuje się za pomocą kodu gwarowego:

A: Nie hejtujże Marysia tyla. Bojcycie łod godziny. Nie zimno wom?

B: Co robiymy? To pogodać nie wolno? Żol ci, to sie przyłącz.

Wyraz hejtować, należący do zasobu najnowszej polszczyzny, został w wypowiedzi ok. siedemdziesięcioletniego mieszkańca Mętkowa zrównany semantycznie ze znaczeniem czasownika plotkować w postaci gwarowej realizacji bojcyć, która pojawiła się w dalszej części komunikatu jako jego rozwinięcie. Nadawcy aktu mownego nie jest zatem znana pełna semantyka pożyczki angielskiej, 
której treść znaczeniowa odnosi się do nowych zjawisk, pierwotnie związanych z komunikacją internetową, a polegających na psychicznym nękaniu osoby lub grupy (Duska \& Mika, 2017, s. 122) ${ }^{8}$. Węzłem semantycznym łączącym obie nazwy jest sem wskazujący na wyrażanie opinii na temat drugiego człowieka. Plotkowanie, w odróżnieniu od hejtu, nie jest jednak aktem agresji werbalnej, nie zakłada obrażania i dyskredytowania jednostki bez podawania argumentów merytorycznych. Potraktowanie hejtowania w kategoriach znaczeniowego ekwiwalentu plotkowania wyrasta zapewne $\mathrm{z}$ ambiwalentnego wartościowania plotki jako wytworu procesu mówienia wymierzonego przeciwko członkom własnej mikrospołeczności, ale mogącego również z definicji zawierać informacje zgodne $\mathrm{z}$ prawdą. W społecznym odbiorze plotkowanie jest jednak traktowane jako mówienie o innych najczęściej niekorzystne, co wynika z uwarunkowań ludzkiej psychiki. Na zrównanie semantyczne obu leksemów wpłynął zatem szereg różnych czynników - pejoratywny wydźwięk obu form, pewne wspólne komponenty znaczeniowe związane z procesem mówienia o innych oraz ograniczone kompetencje mówiącego w zakresie znajomości semantyki struktury zapożyczonej ${ }^{9}$. Wybór pożyczki angielskiej jest więc w wypowiedzi mieszkańca Mętkowa wyborem określonego wariantu, podyktowanym jego znacznym rozpowszechnieniem w komunikacji publicznej.

W dobie przemian społeczno-gospodarczych i cywilizacyjnych na skutek oddziaływania zewnętrznych wzorców językowo-kulturowych systemy dialektalne ulegają stopniowym modyfikacjom, zwłaszcza w płaszczyźnie leksykalnej. Włączanie do własnego, gwarowego repertuaru językowego słownictwa nowego, odnoszącego się do współczesnych realiów jest potrzebą chwili, świadczy bowiem o przynależności jednostki do kulturalnej części społeczeństwa (Kurek, 2003, s. 170). I choć pisze się o konserwatyzmie najstarszego pokolenia użytkowników gwary i o trudnościach z dostosowaniem się do innej, oficjalnej sytuacji komunikacyjnej (Kurek, 2003, s. 138), potrzeba uczestnictwa w kulturze globalnej jest na tyle silna, że determinuje ona sposób językowego zachowania się nie tylko w sytuacji oficjalnej, ale także w kontaktach domowo-rodzinnych i sąsiedzkich. Niemniej należy zwrócić uwagę, że nie wszystkie używane przez starszych nazwy pełnią funkcję nobilitującą, niektóre - wręcz

8 Szczątkowa wiedza na temat formy zapożyczonej pozwala jednak mówiącemu na użycie leksemu częściowo zgodne z jego zakresem znaczeniowym.

9 Na temat przyswajania leksyki obcej przez reprezentantów starszego pokolenia mieszkańców wsi pisała B. Burska-Ratajczyk (Burska-Ratajczyk, 2002). 
odwrotnie - stanowią językowy wyróżnik sprzeciwu wobec tych elementów rzeczywistości zewnętrznej, które mogą zagrażać wiejskiej egzystencji. Jak pisze bowiem H. Pelcowa, „wchodzące na wieś zdobycze cywilizacyjne działają pozytywnie jedynie pod warunkiem, że nie burzą ustalonego sposobu życia i obyczajowości wiejskiej, systemu wartości, tradycyjnych metod komunikacji, współżycia między ludźmi” (Pelcowa, 2009, s. 93).

W wiejskiej przestrzeni kulturowej trwa zatem nieustanny dialog między tradycją a nowoczesnością (Pelcowa, 2002a, s. 385). W analizowanym materiale widoczny jest on także w koegzystencji substratu gwarowego $\mathrm{z}$ warstwą najnowszej polszczyzny w obrębie jednej wypowiedzi. Owo zderzenie różnych odmian języka powoduje, że analizowane zachowania językowe stanowią swoisty „kolaż wiejsko-niewiejski, mający świadczyć [w odczuciu mówiących - BZ] o poszerzaniu się horyzontów kulturowych ich twórców" (Kąś, 1994, s. 38). W rzeczywistości jednak zachowania werbalne mieszkańców wsi obrazują brak dostatecznej kompetencji językowej w zakresie znajomości polszczyzny ogólnej, co przejawia się w przesunięciach semantycznych bądź przekształceniach struktury wyrazu na płaszczyźnie fonetyczno-morfologicznej. Orzekanie jednak, na ile są one powszechne w uzusie najstarszej generacji, a na ile istnieją tylko w idiolektach, wymaga na pewno pogłębionych badań, które warto prowadzić ze względu na fakt, że upowszechnienie indywidualnych interpretacji semantycznych zawsze prowadzi do zmian w systemie gwarowym.

\section{BIBLIOGRAFIA}

Burska-Ratajczyk, B. (2002). Zmiany słowotwórcze i leksykalne w gwarze jako językowy znak socjokulturowych procesów. W S. Gala (Red.), Dialektologia jako dziedzina językoznawstwa i przedmiot dydaktyki: Księga jubileuszowa dedykowana Profesorowi Karolowi Dejnie (ss. 65-74). Łódzkie Towarzystwo Naukowe.

Burska-Ratajczyk, B. (2004). Gwarowe innowacje leksykalne na tle tendencji rozwojowych współczesnej polszczyzny. W K. Michalewski (Red.), Współczesne odmiany języka narodowego (ss. 247-256). Wydawnictwo Uniwersytetu Łódzkiego.

Cienkowski, W. (1972). Teoria etymologii ludowej. Państwowe Wydawnictwo Naukowe.

Cygan, S. (2002). Mowa pokoleń w świadomości mieszkańców wsi Lasocin na Kielecczyźnie. W S. Gala (Red.), Dialektologia jako dziedzina językoznawstwa i przedmiot dydaktyki: Ksiegga jubileuszowa dedykowana Profesorowi Karolowi Dejnie (ss. 83-92). Łódzkie Towarzystwo Naukowe. 
Dunaj, B. (1985). Sytuacja komunikacyjna a zróżnicowanie polszczyzny mówionej. Język Polski, 65(2), 88-98.

Dunaj, B. (2000). O stanie współczesnej polszczyzny. W G. Szpila (Red.), Język trzeciego tysiąclecia: Zbiór referatów z konferencji, Kraków, 2-4 marca 2000 (ss. 25-34). Krakowskie Towarzystwo Popularyzowania Wiedzy o Komunikacji Językowej „Tertium”.

Duska, J., \& Mika, D. (2017). Piętnastowieczne hejstać a współczesne hejtować - o agresji werbalnej w polszczyźnie. Język Polski, 97, 118-126.

Grabias, S. (1982). Paronimia jako proces leksykalny. Socjolingwistyka, 4, 75-88.

Grabias, S. (1991). Pojęcie sprawności językowej. Socjolingwistyka, 11, 47-56.

Grabias, S. (1994). Język w zachowaniach społecznych. Wydawnictwo Uniwersytetu Marii Curie-Skłodowskiej.

Kąś, J. (1992). Społeczno-językowe uwarunkowania interferencji leksykalnej słownictwa gwarowego i ogólnopolskiego (na przykładzie gwar orawskich). W J. Maćkiewicz \& J. Siatkowski (Red.), Język a Kultura: T. 7. Kontakty języka polskiego z innymi językami na tle kontaktów kulturowych (ss. 95-102). Wydawnictwo Uniwersytetu Wrocławskiego.

Kąś, J. (1994). Interferencja leksykalna słownictwa gwarowego i ogólnopolskiego (na przykładzie gwar orawskich). Uniwersytet Jagielloński.

Kąś, J., \& Kurek, H. (2001). Język wsi. W S. Gajda (Red.), Najnowsze dzieje języków słowiańskich: Język polski (ss. 440-459). Uniwersytet Opolski - Instytut Filologii Polskiej.

Kucała, M. (1960). O słownictwie ludzi wyzbywających się gwary. Biuletyn PTJ, 19, 141-156.

Kucharzyk, R. (2002). Język wsi z perspektywy autochtonów. W S. Gala (Red.), Dialektologia jako dziedzina językoznawstwa i przedmiot dydaktyki: Księga jubileuszowa dedykowana Profesorowi Karolowi Dejnie (ss. 277-286). Łódzkie Towarzystwo Naukowe.

Kurek, H. (1994). Zachowania komunikacyjne mieszkańców współczesnej wsi. W S. Gajda \& J. Nocoń (Red.), Kształcenie porozumiewania się (ss. 109-114). Wydawnictwo Uniwersytetu Opolskiego.

Kurek, H. (1995). Przemiany językowe wsi regionu krośnieńskiego: Studium socjolingwistyczne. Towarzystwo Autorów i Wydawców Prac Naukowych „Universitas”.

Kurek, H. (2003). Przemiany leksyki gwarowej na Podkarpaciu. Towarzystwo Autorów i Wydawców Prac Naukowych „Universitas”.

Kurek, H. (2012). Czynniki socjolingwistyczne a przemiany polszczyzny mówionej w ostatnim półwieczu. W H. Kurek (Red.), Języki słowiańskie w ujęciu socjolingwistycznym (ss. 85-92). Księgarnia Akademicka.

Kurek, H. (2014). Tożsamość kulturowa polskiej wsi w epoce globalizacji i przemian społeczno-ekonomicznych. W M. Rak \& K. Sikora (Red.), Badania dialektologiczne: Stan, perspektywy, metodologia (ss. 45-54). Księgarnia Akademicka.

Kurek, H. (2018). Słownictwo gwarowe w epoce globalizacji. W R. Przybylska, M. Rak, \& A. Kwaśnicka-Janowicz (Red.), Historia języka, dialektologia i onomastyka w nowych kontekstach interpretacyjnych (ss. 203-209). Wydawnictwo Uniwersytetu Jagiellońskiego.

Miodunka, W. (1974). Funkcje zaimków w grupach nominalnych współczesnej polszczyzny mówionej. Państwowe Wydawnictwo Naukowe. 
Pelcowa, H. (1999). Przeszłość w językowym obrazie świata współczesnej wsi. W A. Pajdzińska \& P. Krzyżanowski (Red.), Przeszłość w językowym obrazie świata (ss. 253-267). Wydawnictwo Uniwersytetu Marii Curie-Skłodowskiej.

Pelcowa, H. (2000). Kompetencja językowa i kompetencja komunikacyjna mieszkańców wsi regionu lubelskiego. W W. Książek-Bryłowa \& H. Duda (Red.), Język polski: Współczesność, historia (ss. 91-104). Wydawnictwo Uniwersytetu Marii Curie-Skłodowskiej.

Pelcowa, H. (2002a). Dialektologia wobec wyzwań XXI wieku. W S. Gala (Red.), Dialektologia jako dziedzina językoznawstwa i przedmiot dydaktyki: Księga jubileuszowa dedykowana Profesorowi Karolowi Dejnie (ss. 383-392). Łódzkie Towarzystwo Naukowe.

Pelcowa, H. (2002b). Leksykalne wyznaczniki integracji i dezintegracji jako odzwierciedlenie zachowań językowych mieszkańców wsi. W H. Sędziak (Red.), Polszczyzna Mazowsza i Podlasia: Słownictwo i frazeologia polszczyzny mówionej (ss. 23-36). Łomżyńskie Towarzystwo Naukowe im. Wagów.

Pelcowa, H. (2009). Trwanie i przemijanie w języku i obyczajowości wiejskiej. W J. Adamowski \& J. Styk (Red.), Tradycja w tekstach kultury (ss. 89-100). Wydawnictwo Uniwersytetu Marii Curie-Skłodowskiej.

Pelcowa, H. (2013). Dynamika zmian w polskich gwarach i dialektach w ostatnim siedemdziesięcioleciu. W A. Dunin-Dudkowska \& A. Małyska (Red.), 70 lat współczesnej polszczyzny: Zjawiska, procesy, tendencje: Ksiega jubileuszowa dedykowana profesorowi Janowi Mazurowi (ss. 373-397). Wydawnictwo Uniwersytetu Marii Curie-Skłodowskiej.

Piechnik, A. (2009). Wizerunek kobiety i mężczyzny w językowym obrazie świata ludności wiejskiej (na przykładzie gminy Zakliczyn nad Dunajcem). Wydawnictwo Uniwersytetu Jagiellońskiego.

Piechnik, A. (2015). Dyferencyjne ekspresywizmy gwarowe w języku małopolskich gimnazjalistów. W R. Dźwigoł \& I. Steczko (Red.), Dialog z Tradycją: T. 3. Język - komunikacja kultura (ss. 459-466). Collegium Columbinum.

Piechnik, A. (2016). Słownictwo ekspresywne młodych mieszkańców wsi w świetle procesów globalizacyjnych. W H. Kurek, M. Święcicka, \& M. Peplińska (Red.), Globalizacja a przemiany języków słowiańskich (ss. 300-307). Wydawnictwo Uniwersytetu Kazimierza Wielkiego.

Piechnik, A. (2019). Styl urzędowy mieszkańców wsi (na przykładzie podań do wybranych ośrodków pomocy społecznej w południowej Małopolsce). Księgarnia Akademicka. https:// doi.org/10.12797/9788381380621

Piechnik-Dębiec, A. (2011). Kultura tradycyjna a kultura współczesna na wsi (w świetle ustnych przekazów gwarowych z Małopolski). W J. Adamowski \& M. Wójcicka (Red.), Tradycja dla Współczesności: Ciagłość i zmiana: T. 4. Tradycja w kontekstach kulturowych (ss. 147-154). Wydawnictwo Uniwersytetu Marii Curie-Skłodowskiej.

Ziajka, B. (2014). Językowo-kulturowy obraz świata społeczności wiejskiej utrwalony w przezwiskach i przydomkach (na przykładzie nieoficjalnych antroponimów mieszkańców Zagórza $i$ wsi okolicznych w powiecie chrzanowskim). Wydawnictwo LIBRON. 


\section{Nowe zachowania językowe u najstarszego pokolenia mieszkańców wsi}

Celem artykułu jest analiza tych zachowań językowych najstarszych mieszkańców wsi, które wynikają z uniwersalizującego oddziaływania na język ludowy kultury ogólnej. Współczesne tendencje globalizacyjne, w sposób szczególny zaznaczające się w środowiskach wiejskich, powodują, że najstarsze pokolenie zmuszone jest włączać do własnego, gwarowego repertuaru językowego nowe słownictwo odnoszące się do współczesnych realiów, częstokroć niemieszczących się w sferze kulturowej, społecznej i obyczajowej wiejskich wspólnot. Egzemplifikacja materiałowa, którą stanowią zachowania werbalne zebrane w latach 2015-2020 na terenie wiejskiej gminy Babice w powiecie chrzanowskim, wskazuje jednakże na brak kompetencji językowej mieszkańców wsi w zakresie znajomości najnowszej warstwy polszczyzny ogólnej. W zachowaniach werbalnych najstarszej grupy wiekowej pojawiają się bowiem liczne formy dewiacyjne, słownictwo nowe często jest wymawiane z zachowaniem tradycyjnej fonetyki gwarowej. Dochodzi także do przekształceń na płaszczyźnie morfologicznej. Przyczyną tych modyfikacji bywają trudności artykulacyjne połączone z brakiem wiedzy o ich etymologii. Nowe wyrazy nie zawsze są w pełni zrozumiałe dla starszego pokolenia, dlatego też przenoszeniu jednostek ogólnopolskich do kodu gwarowego często towarzyszą przesunięcia semantyczne.

Słowa kluczowe: komunikacja językowa, język mieszkańców wsi, innowacje leksykalne

\section{New Linguistic Behaviors in the Eldest Generation of Village Inhabitants}

The objective of the paper is analysis of the eldest village inhabitants' linguistic behaviors which result from the universalizing influence of general culture on folk language. The contemporary globalizing tendencies which are strongly reflected in rural environments result in the fact that the eldest generation is forced to include new words in their own dialectal vocabulary that refer to modern realities that often do not fall within the scope of the cultural, social and customary sphere of rural communities. The materials, which include verbal behaviors collected in 2015-2020 in the rural commune of Babice in Chrzanów district, indicate the villagers' lack of linguistic competence in terms of knowledge of the newest layer of general Polish. This is because, in the verbal behaviors of the members of the eldest age group, we can find numerous forms of deviation, and new words are often pronounced using traditional dialectal phonetics. Morphological transformations also occur. The reasons for these transformations include articulation difficulties combined with etymological unclearness. 
New words are sometimes unclear to elder people, which is why semantic shifts often occur when transferring general Polish units into the dialectal code.

Keywords: rural language, verbal communication, lexical innovations

\section{Notka o autorce}

Beata Ziajka (beata.ziajka@uj.edu.pl) - doktor nauk humanistycznych w zakresie językoznawstwa, adiunkt w Katedrze Współczesnego Języka Polskiego Wydziału Polonistyki Uniwersytetu Jagiellońskiego. Autorka monografii Językowo-kulturowy obraz świata społeczności wiejskiej utrwalony w przezwiskach i przydomkach (na przykładzie nieoficjalnych antroponimów mieszkańców Zagórza i wsi okolicznych w powiecie chrzanowskim) (2014); współautorka czterech zeszytów Słownika gwar polskich oraz Słownika gwar małopolskich. Zainteresowania naukowe: język mieszkańców wsi w ujęciu etno- i socjolingwistycznym, antroponimia ludowa, leksyka ekspresywna, leksykografia gwarowa, teoria i metodologia badań pragmalingwistycznych.

BeataZiajka (beata.ziajka@uj.edu.pl) - PhD in linguistics, assistant professor in the Department of Contemporary Polish at the Faculty of Polish Philology of Jagiellonian University. Author of the monograph Jezykowo-kulturowy obraz świata społeczności wiejskiej utrwalony w przezwiskach i przydomkach (na przykładzie nieoficjalnych antroponimów mieszkańców Zagórza i wsi okolicznych w powiecie chrzanowskim) [Linguistic and Cultural Picture of the World of the Rural Community Preserved in Nicknames and Assumed Names (on the Basis of Unofficial Anthroponyms of the Inhabitants of Zagórze and Neighbouring Villages in the Chrzanów District), 2014]; co-author of four issues of the Słownik gwar polskich [Lexicon of Polish Dialects] and the Słownik gwar małopolskich [Lexicon of Lesser Poland Dialects]. Scientific interests: villagers' language in the ethnolinguistic and sociolinguistic perspective, folk anthroponymy, expressive lexis, dialectal lexicography, theory and methodology of pragmalinguistic studies.

Publication History: Received: 2020-09-29; Accepted: 2021-02-18; Published: 2021-12-23 